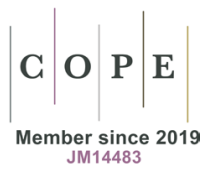

\title{
The Category of Ugliness in Historie maniaków by Roman Jaworski
}

\section{SUMMARY}

The article undertakes to interpret the collection of short stories titled Historie maniaków by Roman Jaworski using the category of ugliness. So far, this work has been analysed through a different aesthetic category, namely the grotesque, while the author himself drew attention in the discussed collection of short stories to ugliness and recommended that it should be chosen as the principle perspective. The analysis focuses on the impact of the ugliness category on the shaping of elements of the world presented in the work: the creation of the characters and their corporeality, settings, as well as the very composition of the collection and the construction of the language used by the author. The paper finishes with an attempt to interpret Historie maniaków using contemporary humanistic theories, which consider the category of ugliness as a positive value.

\section{Keywords}

abject, ugliness, corporeality 
Roman Jaworski is a writer who is associated by literary scholars primarily with the category of the grotesque and parody. Michał Głowiński called him the precursor of the parody and grotesque current in Poland, ${ }^{1}$ stressing the impact of his work on the development of this trend. On the other hand, Jaworski created an innovative concept of the aesthetics of ugliness, which, oddly enough, occupies a marginal place in the research on his work and has not yet been widely discussed. Probably the reception of his literary output has been influenced by the fact that, at the beginning of the 20th century, the category of ugliness was identified with the grotesque. Nowadays, however, it is possible to distinguish between the two aesthetics and, despite many common features, to attempt to define their distinctiveness. Therefore, it is worth rereading Jaworski's work, but this time through the prism of the category of ugliness. The author's interest in this very aesthetics is visible in all his works, yet it is the collection of short stories titled Historie maniaków [Stories of Maniacs] that is of particular interest due to the presence of the ugliness category. The book, which was published in 1910, is a testimony not only to the writer's aesthetic preferences, but also to his extensive reflections on aesthetics, its place and role. Jaworski reached for ugliness while constructing the presented world and he also directly expressed his views on his aesthetic tastes in passages taking on the character of quasi treatises. In terms of the category of ugliness, he was therefore both a practitioner and a theoretician, which distinguishes him from not only Young Poland artists but also from the later ones. It is certainly worth tracing Jaworski's original approach to the category of ugliness, both in the theoretical component and in numerous artistic realisations. This analysis included the stories from the collection Historie maniaków and the ugliness present in them was investigated from the point of view of the construction of characters and their corporeality, the language which they used as well as the overall composition of the collection. The layer of meaning was explored for the values which are connoted by ugliness used in the work and the meanings it carries. The vision of total ugliness, both declared in theory and consistently implemented in the stories, seems very interesting and worthy of attention. The spectre of this phenomenon in Jaworski's case requires a thorough analysis of his work, the use of a new research key and a deepened reflection, which must be free from the well-worn interpretation based on the grotesque.

\section{Jaworski's theory of ugliness}

At the beginning of a short story tilted "Amor milczący" [Silent Amor], Jaworski declared that in spite of "a pretentious gang of lyrical stinkers," "2 "he wishes to introduce literature which is ugly and difficult in Poland." 3 His

\footnotetext{
${ }^{1}$ Michał Głowiński, "Sztuczne awantury," introduction to Roman Jaworski, Historie maniaków (Krakow: Wydawnictwo Literackie Krakow, 1978), 22.

2 Roman Jaworski, Historie maniaków (Warsaw: Biblioteka Analiz, 2004), 138. [Unless indicated otherwise, quotations in English were translated from Polish]

${ }^{3}$ Jaworski, Historie maniaków, 139.
} 
goal was a literature which is ugly and difficult to read, as he extended his thought later, saying that the reading of Historie maniaków should not take place "on a chaise longue and with a full stomach." terature intended for thoughtless and easy entertainment. In this way, he manifested not only his poetics, but he also pointed out the thematic areas he would explore in his works. The formal ugliness coincided in this auto-thematic narrative with the ugliness of the presented content. Jaworski referred to Historie maniaków as "unmerry stories," and he justified his choice of the topic in an ironic way: "all the merry ones sold thousands of copies." This difficulty and ugliness, to which he intentionally aspired, was to be the guarantee of uniqueness, a distinguishing feature among other works. Using the words of the narrator, Jaworski warned the readers not to look for "banal morbidity" in the stories. He suggested that it is through reading that it is possible to get to know "people who tend to be overlooked, living a double life" - ugliness was not merely a provocation, but it was semantically and epistemologically characterised by its cognitive function. The narrator's words have a metaliterary character and the speaker can be identified with the writer himself, who - with a considerable amount of irony and perversity - draws a vision of his entire work, specifies the conditions of reading it and gives instructions on how to read and interpret his prose. Another protagonist of Jaworski's prose speaks about the aesthetics of ugliness in a different way, no longer provocative but rather elevated and almost pathetic. The journalist in the short story titled "Trzecia godzina" [The Third Hour] could be the porte parole of the author, and his statements can be viewed as defining the author's aesthetic concept:

The structure of official aesthetics is collapsing, yearnings for beauty die down. There are no beautiful people, no long-haired troubadours or robust knights. The people of our modern times are ugly. They boldly face a life of abomination, they get stuck in the trash, and they only sometimes quietly long for a better life. Their suffering must be ugly and odd, and this is all their beauty. Let us teach the new beauty, let us get acquainted with our fellows, with our brothers. While writing about them, let us not write beautifully about their oddity; instead, let us talk strangely about their ugly beauty. Let us create the necessary, contemporary aesthetics of ugliness, let us give it artists, let us preach a religion, let us look for worshippers. ${ }^{7}$

The views of the protagonist of the work show Jaworski's deep reflection on aesthetics, its place in the world of his day and the system of values. It is worth drawing attention to the statement that the previous model of aesthetics lost its relevance and it is necessary, following the thought of Nietzsche, to redefine all values. The writer urges for ugliness in the name of

\footnotetext{
${ }^{4}$ Jaworski, Historie maniaków.

${ }^{5}$ Ibid.

${ }^{6}$ Ibid.

${ }^{7}$ Ibid., 143.
} 
truth, which is free from the artificiality of idealisation. Using this aesthetic category, he wants to undermine and discredit the aesthetic cliché based on the stereotypical understanding of beauty. The programmatic appreciation of ugliness is also a manifestation of the aesthetic rebellion against the petite bourgeoisie value system. The writer mocks the readers who, lying down, entertain themselves with the book only to find "banal morbidity" in it. They bring to mind the provincial bourgeois that lacks higher aspirations. The behaviour of philistines, criticised by Young Poland bohemians, will be depreciated by later artists. Thus, Jaworski represented a trend that has not lost its importance in the subsequent decades. The writer defied the traditional scale of values and sought originality in undermining the current aesthetic standards (also with regard to literary conventions).

In his vision of the world, there is no place for over-aesthetic knights and troubadours, therefore he appreciates ugly people who face not so much the prose of life as its abomination. The focus of the writer's attention is on people who were previously marginalised, stigmatised, and pathologised to some extent not conforming to the "standards." The way of characterising the group, which is the centre of Jaworski's interest, brings to mind the abject from the theory of Julia Kristeva. ${ }^{8}$ According to one of the definitions of this concept, the abject in social terms is represented by those who do not fit into the specific identity adopted by a given community, but they are also not outside it. ${ }^{9}$ Like the abject, the ugliness of Jaworski's characters repulses and at the same time fascinates. The author rehabilitates his abjective characters and treats their perspective as the model one, making their ugliness and oddity a positive value. In this way, he suggests that literature should turn to everyday reality, which is not free from abomination.

Rejecting idealisation does not, however, mean turning towards verismo: Jaworski does not reproduce reality, but instead creates it using the category of ugliness. The world presented in his stories is constructed of fantastic and unbelievable elements, which correspond to the oneiric element present in the stories. The previously quoted fragment can be called the aesthetic manifesto of Jaworski, in which he presents his artistic credo. The aesthetics of ugliness, which he proclaimed, was to be realised through the subject matter of short stories and a sophisticated form of presentation. Jaworski's theoretical consciousness makes Historie maniaków an important voice in the literary discussion about values and about the place of what is despised, repulsive, stigmatised in the modern world, and the writer himself becomes a precursor of the category of ugliness as well as a visionary: he is the first to formulate a literary programme which confirmed its validity in the following decades. ${ }^{10}$

${ }^{8}$ Cf. Julia Kristeva, Potęga obrzydzenia. Esej o wstręcie, trans. Maciej Falski (Krakow: Wydawnictwo Uniwersytetu Jagiellońskiego, 2007).

${ }_{9}$ Izabela Kowalczyk: abiekt [the abject] in Encyklopedia gender. Płeć w kulturze, eds. Monika Rudaś-Grodzka, Katarzyna Nadana-Sokołowska, Agnieszka Mrozik, Kazimiera Szczuka, Katarzyna Czeczot, Barbara Smoleń, Anna Nasiłowska, Ewa Serafin, Agnieszka Wróbel (Warsaw: Czarna Owca, 2014).

${ }^{10}$ Głowiński, "Sztuczne awantury," 22. 


\section{Ugliness in Jaworski's practice: Corporeality}

Jaworski's theory of aesthetics puts ugliness at the centre not as an abstracted aesthetic value, but as an ugly human being who, according to the writer's words, comes from the present day. It is the human being - their ugliness, suffering and eccentricities - that the author wants to explore. The confirmation of the writer's words can be found in the thematic layer of all the stories, since it is the protagonists, or more precisely their defects, that are the main topic Historie maniaków. A teasingly complex and unrealistic plot only serves to expose further human distortions. In addition, the settings are also subordinated to the ugliness of the protagonists: they merely complement the caricatured physicality and mentality of the characters. The impact of the category of ugliness is not limited only to the creation of the presented world, it can also be observed in the layers of the composition and language of the text.

The author places the characters' ugly bodies, often marked by old age, diseases and handicaps at the centre of his deliberations. Physical ugliness represents an aesthetic dominant in all the stories that make up this original volume. The procession of characters marked by physical ugliness creates an image modelled on danse macabre. It is led by a crippled old woman with a lisp, along with a stinking stallholder selling dirty sweets and dried oranges, a dark, half-witted peasant who moves his dirty finger on a greasy book, a creeping "ragged old hag, weeping through her bleary eyes, regurgitating prayers through her toothless mouth"11 or a lipsticked monster, whose mouth reeked of herring and tobacco - anonymous characters who are not in the centre of events and whose presence confirms the thesis about the ubiquitous ugliness which affects all senses: sight, hearing and smell. The author seems to be fascinated by the abomination of the human body. With misophonic precision, he keeps track of sounds that are disgusting: Honorcia's smacking her lips and crunching pretzels, ominous tickling from under Pichon's rotten teeth, the sinister chomping of Dr. Lipek's patients or the wheezing of a dying baby crushed by its mother's corpse. The accumulation of disgusting sounds makes the reader realise how abundant the language used to express abominations is. This language also strongly emphasises human corporeality in its most repulsive dimension: "the gibberish of the mute was heard, there were slithering squeals of a little waif in a cesspit and cries of birds for the knocked nest, and the ante-mortem gurgling of hanged people was roaming." 12

The physical ugliness of the depicted characters also appears in Jaworski's work as a sign of posthumous decay. Their bodies are rotting; they are damaged and incomplete, repugnant with their smell and disgusting because of the sounds which they make. The repulsive descriptions of corporeality seem to remind us of the fragility of human existence. The physical ugliness of the characters is not only an extremely suggestive way of

\footnotetext{
${ }^{11}$ Jaworski, Historie maniaków, 139.

12 Ibid., 167.
} 
evoking a sense of disgust in the reader. It also characterises the condition of the portrayed: they are depicted as if they were no longer alive; they seem to be dead still during their lifetime.

What is more, Jaworski uses the relationship of the categories of ugliness and corporeality to create a specific mood: the short stories comprising Historie maniaków are riddled with the putrid smell of autumn, the stinking sap of a dead cuckold, the odour of the corpse or lustful embraces smelling of vomit. These extremely evocative images, affecting the imagination and pervaded with synesthesia, attack the reader with their bluntness.

Jaworski places some characters whose bodily ugliness he equips with additional meaning above those whose ugliness constitutes a kind of background for the plot. Old age, infirmity and poverty, so strongly exposed in secondary characters, give way to illness or other ailments. The crippling physiognomy of the main characters of individual stories is marked semantically. Medi, a girl with a red spot on her face, Mr Pichon, a squint-eyed epileptic, doctor Fallus with his "dangling figure," for which he given his name, or finally patients with mental disorders from the health care institution of Dr. Lipek - what these characters have in common is the "proper" ugliness, being a carrier of meaning in the work. Their disabilities are a stigma, on the one hand, and a sign of their uniqueness, on the other. These shortcomings make them suffer, yet the defects also make them extraordinary, make them stand out against a bland, anonymous crowd.

A spot on the cheek of the eponymous character of the story tilted "Medi" is the reason for her misfortune and, consequently, her death. The skin defect resulting from a childhood illness made the father, a perfectionist and a glorifier of perfection, turn away from his child. He claimed that "perfection should avoid fruit that becomes unnecessary due to some deficiency or error."13 After the father of the family leaves, the rejected and abandoned mother becomes mentally ill, blaming the family misfortune on Medi and her spot. The short story ends with the death of a child who is either deprived of life by her insane mother who cannot stand the fact that she exists, or commits suicide as a result of the lack of acceptance and contempt of her mother. The stigmatising ugliness was the cause of the family tragedy.

It was the disease, which was depicted with the use of ugliness, that brought misfortune to Jerzy, nicknamed Dr. Phallus, an attorney from the short story titled "Amor Milczący." His physiognomy, which carried unambiguous connotations, was not the main cause of the character's problems. The attorney suffered from "a demonic manner," "mystical incapacity" or "a painful stigma" - the protagonist's affliction was not named directly, and the terms proposed by the author are metaphorical. The doctor was depicted as a torn figure, a victim of the struggle of internal forces: "As a result of every undertaking or a bold gesture, a mysterious companion-kobold sprang out, like a clown on a wire, somewhere from the depths of the attorney's mouth, and withholding the ending, reported his veto in the wildest

${ }^{13}$ Ibid., 61. 
of tones."14 Burdened by an enigmatic affliction, Jerzy was not able to control his behavior, he was powerless in the face of reactions that he tried to curb with great effort. This "mysterious veto" was manifested by a broken voice, the convulsive trembling of his hands, the misty tearing of the eyes or a painful half-smile. The protagonist's dilemma and his physical suffering were extracted with the use of the category of ugliness, which was reflected in his physiognomy: "In this way he conveyed in the expression of his face the struggle of the forces, which were hostile to each other and mysterious." 15 The inability to express his views unequivocally complicated his professional life and was also the cause of his failure in his personal life. The enigmatic affliction made Jerzy unable to declare love to his beloved, but also accept his feelings for her. Not only did his ugliness mark his physiognomy, but it also influenced his inner life and caused personal tragedy.

Interestingly, the category of ugliness in the context of the characters' corporeality has not been applied in the same way throughout the text. Its most original realisation is undoubtedly the story titled "Trzecia godzina," which is of particular importance for the whole collection. The fragment quoted earlier, which might be well regarded as Jaworski's aesthetic manifesto, is a part of it. One can be tempted to say that the way ugliness is used in this work best fulfills the writer's postulates. The ambivalent perception of the ugliness of the characters comes as a surprise in this story. The physical defect is not perceived as a disadvantage - it is turned into a positive value. The main character of the story drew knowledge about himself and the world from the visions which he had during the seizures of epilepsy and narcolepsy: "He drew his views from the sick imaginings to which he succumbed when, all of a sudden, he was grabbed by a muscle contraction near his heart and gently placed on the ground."16

Visions and delusions were valued positively by him, and the bout of the disease itself was described as noble and indicative of his extraordinary sensitivity and nonconformity: "He wiped the foam from his mouth, a trace of noble indignation at the revealed eternal abomination, and girded his torn forehead with a red foulard."17 One distinguishing feature of Pichon was the strabismus, thanks to which he saw more than the average person: the change of the viewing angle broadened his horizons and made it possible to reach content which remained unattainable for others. The strabismus was by no means a shortcoming, but instead, it was treated as a gift, a kind of anointment: "He could reason calmly, attributing all his misfortunes to a strabismic error in his eyes which he had received as a gift from birth."18 The importance of Pichon's disability was emphasised by the fact that, not having a descendant, he chose as his heir Franek, a boy who "flashed with his dirty eyes, having a bad squint."19 In the case of this character, ugliness

\footnotetext{
${ }^{14}$ Ibid., 185.

15 Ibid., 83.

${ }^{16}$ Ibid., 82.

17 Ibid., 89.

18 Ibid., 81.

${ }^{19}$ Ibid., 139.
} 
is a sign of being above-average, which entitled him to gain knowledge inaccessible to others. Due to his ugliness he became worthy of knowing the mystery of the world - its "ruler who only craved for the death of people," 20 and thanks to his uniqueness he was able to discuss with the stone statues which he called the prophets and learn about their wisdom. The ugliness depicted in "Trzecia godzina" thus becomes a carrier of metaphysical truth.

\section{The setting}

In Jaworski's concept, ugliness is strongly connected with the human body. The writer uses this aesthetic category to explore corporeality and to present those aspects which are not subject to aestheticisation. Ugliness is also a relevant element of the presented world and it shapes the mood of the work. The space marked by it creates a background for equally ugly characters and events. This category organises not only the presented plant scenery and greenery, it is also used to show the buildings and interiors where the story is set.

In Jaworski's creation, the natural world is shabby and crippled. Vegetation is shown in such a way so as to bring out its repulsive side. In creating an image of nature, the writer used ugliness affecting all the senses, which is characteristic of his prose. The scenery depicted in Historie maniaków prompts disgust because of its smell, it disturbs with sounds and repulses with its appearance: "At that time, he had to wander around the edges of a dead pond which was wheezing with rotten sludge. Rummaging in green-leafed yarns, he was looking for his lily, his nenuphar, the flower of past beliefs. The pond stank, the toads were mumbling." 21 The green idyll changes in Jaworski's work into disgusting and repulsive places. It is virtually impossible to find animals in his prose that would not be characterised by ugliness, or would not trigger associations with this category. When the author creates the image of horses in the story titled "Miał iść" [He Was Going to Go], he stresses the specificity of their skeletons: "Under the wall of glows, he saw the skeletons of sleeping horses crowded together in herds. Their ribs and tibias, which were soaked in light, formed a great symbol of silent history." 22

It is not difficult to guess that the interiors evoked in the narrative will be consistent with the aesthetic vision of the whole. Jaworski chooses dirty chambers filled with the pungent fug of sauerkraut cucumbers, wretched mud huts supported by rotten piles or rat-infested rooms as his settings: "In the corners of the chamber lofty rat traps shot up like ornamental water towers." ${ }^{23}$ The very choice of settings is subordinated to Jaworski's aesthetic imperative. The events which he describes take place in such suggestive places as a psychiatric hospital; a poisonous cake confectionery with the grotesque name of "The Coltish Witch's Cave"; and a funeral house or a brothel,

\footnotetext{
${ }^{20}$ Ibid., 135.

${ }^{21}$ Ibid., 110.

22 Ibid., 28.

${ }^{23}$ Ibid., 119.
} 
where specific customs and manners are preferred: "Whistling, he slammed open the door of the living room, which was considered the first evidence of refinement there and found the interior unexpectedly dark and empty." ${ }^{24}$

\section{Composition and language}

Another important element of Historie maniaków is its composition. In the introduction to the 2004 edition, Piotr Kitrasiewicz draws attention to the precursory nature of Jaworski's writing, proving this on the basis of juxtaposing elements characteristic of the Young Poland poetics in his work against the background of which the elements constituting a significant novelty clearly stood out. One of them, according to the scholar, is the composition of the work ${ }^{25}$ One can be tempted to develop this observation, arguing that Jaworski's choice of literary devices is greatly affected by ugliness. For instance, ugliness is revealed by the original construction of the plot, which the writer completely freed from the principles of logic or even probability. The cause and effect relationship becomes distorted in Historie maniaków, and events are marked by absurdity and unpredictability. Jaworski's short stories are characterised by the lack of a clearly defined time frame or background of events. The strongly accented impressionism makes the events presented by the writer fragmentary and ephemeral, resembling an attempt to grasp the state closer to the landscape, without drafting a fast-moving plot. The composition also determines how this writing should be read: it requires attention. And this is where Jaworski's novelty is manifested, namely in the creation of the anti-text, anti-literature with the help of the category of ugliness long before the postulates of postmodernists. The composition of Historie maniaków contradicts the conventional way of constructing the narration and the plot. Its otherness goes beyond the framework of a traditional novel. If one considers what is traditional, familiar and consistent with the principles in the context of something "pretty," then the bold and unusual form chosen by Jaworski may be the realisation of "ugliness" in the composition.

Jaworski's way of constructing the plot also determined a certain stylistic mannerism: his fantastic world, far from being predictable, is described with sentences as incomplete as the presented plot. Creation using the category of ugliness takes place also on the level of stylistic construction in the writer's prose: sentences tend to be flawed, torn, crippled, often short, single-worded or, in other passages, pretentiously complex, which can be seen as a parody of the Young Poland style. The juxtaposition of such forms intensifies the effect achieved with the help of a specifically built plot and embedding the extraordinary protagonists in it, the eponymous "maniacs," i.e. disturbed people, misfits, characters from the borderland of worlds, who were created in spite of the habits and expectations of the reader.

\footnotetext{
${ }^{24}$ Ibid., 92.

${ }^{25}$ Cf. Piotr Kitrasiewicz, introduction, in Roman Jaworski, Historie maniaków (Warsaw: Wydawnictwo Naukowe PWN, 2004).
} 


\section{Provocation with ugliness}

The ludic aspect of the work is extremely interesting. It is accomplished with the use of the category of ugliness: the writer uses this aesthetics to play with the reader. It may seem that this game is intended to test the limit of the recipient's good taste. After all, it is impossible to remain indifferent to the fragments of stories in which the accumulation of ugliness is a provocation, consciously leading to a conflict with the reader.

She was sowing where her lost sons and daughters went. And mourning purples were seeping, and night birds caught them on their wings and, dragging them, they took them far away to homesteads, where infants whimpered and where a blind man's violin wailed in the attic, where an ill lad was at a harlot and where resinous wood smouldered under a dried haystack, where a grandma stole silver coins for her hungry grandchildren and where a maid made love to a stranger, where a madman hung from the hospital bars. ${ }^{26}$

In these words, Jaworski defines the setting of the short story tilted "Mial iść." It opens the whole collection, and the provocative fragment is placed at the beginning like a warning, or perhaps a kind of test for the audience - will the reader dare to turn the page and continue to read the text full of such images? Such tension-building, shocking the reader with provocative ugliness is not a one-off device, and it can also be found in the story titled "Bania doktora Lipka" [Doctor Lipek's Gourd]. The short story opens with a strange-sounding apostrophe used to address eyelashes which are faded from looking at horrors, faint hares snatched by hawks, babies who died without being baptised, a drunken hangman, an unsightly stinking girl at the corner, a mangy little dog, or Jewish cemeteries from which leprosy spreads to the city - or the recipients of tender greetings from Christ's mercenaries, as patients of Dr. Lipek, a psychiatrist, dubbed themselves. Ugliness, in the case of the above mentioned enumeration, has a comedic effect, which in turn leads directly to the grotesque - iconoclastic, surprisingly rebellious, even with contemporary reading. As Krzysztof Kłosiński rightly observes, this effect was achieved with the use of diminutives - "(...) a mother with her daughterling boarded a ferry prom. The daughterling was very much in love and she was about to become a great lady. Only the horses bolted away and the little carriage fell into the water, and the daughterling became a little fishy"27 - as well as the juxtaposition of diminutives and sublimation used concurrently with reference to either a commonplace or an ugly designate. ${ }^{28}$

It seems particularly provocative to use the category of ugliness in the context of the subject of sexuality. The protagonist of "Trzecia godzina,"

\footnotetext{
${ }^{26}$ Jaworski, Historie maniaków, 19.

27 Ibid., 32.

${ }^{28}$ Krzysztof Kłosiński, Wokót „Historii maniaków.” Stylizacja, brzydota, groteska (Krakow: Wydawnictwo Literackie, 1992), 191.
} 
Mr. Pichon, felt an undisguised fascination with Honorcia's physicality, especially one detail of her body, namely a wart: "He admired the black velvet dressing gown embroidered in yellow flowers, its deep cuts on the neck and back, and especially a serious wart, which sat like a seductive cuckoo on her protruding gaunt shoulder blade." ${ }^{29}$ The wart affected its aficionado so much that he could not refrain from touching it with his lips, for which he was severely rebuked by its owner. It is possible to see here the conceptualisation of the vetula topos, which has been present in literature and fine arts for centuries. Kristeva refers to it in her reflections on the abjective mother. ${ }^{30}$ Honorcia becomes the equivalent of the archetypical figure of a repulsive hag, embodying all the taediogenic factors, ranging from the wrinkled, sunken body covered with warts to the detestable smell, imminent death and the evocations of the decomposing corpse. The vetula represented an articulation of male sexual aversion. Constructing an image of erotic fascination with the use of the category of ugliness and disgust bears the hallmarks of perversion, which once again appeared in the short story titled "Amor milczący": "Never have I touched a young, alive body with a longing hand, my youthful lips rubbed their purple on the grease of the grey-haired plaits and on the coarse skin of dried breasts. A gigolo and a pupil of a half-corpse, I think of love deathly." ${ }^{31}$ Also in this case, it is possible to observe a clear gradation of the device used. The purport of "deathly love" seems much stronger than that of an innocent kiss on the wart. Love with a hint of necrophilia, a combination of excitement and normally repulsive elements, becomes another way to shock readers by violating a cultural taboo.

Being iconoclastic, the provocations with ugliness had also humorous overtones. Not only did they arouse aversion, but they also allowed the author to create jocular images with the help of that sophisticated sensitivity, as in the case of the situation in which a national monument of the bard was desecrated with a certain physiological activity: "Clumsy and huge, he sat under the statue of a national bard, he opened an umbrella, dropped his pants and he did a very ugly thing under the umbrella, polluting the inviolable place."32 The clash of two opposing categories, namely sublimity and humour legitimised by ugliness, allowed the author to create a scene that attacks the widely recognised authorities. The play of contrasts and disharmonies irretrievably remove pathos from Jaworski's literary output and depict him as a writer capable of creating images which are far from stereotypes.

\section{The grotesque}

The aforementioned combination of ugliness and humor evokes associations with the grotesque. This category is an important element in Jaworski's prose. Due to the presence of the grotesque in his works, the writer is

\footnotetext{
${ }^{29}$ Kłosiński, Wokót „Historii maniaków." Stylizacja, brzydota, groteska, 92.

${ }^{30}$ Winfried Menninghaus, Wstręt. Teoria i historia, trans. Grzegorz Sowiński, (Krakow: Universitas, 2009), 15.

${ }^{31}$ Jaworski, Historie maniaków, 193.

32 Jaworski, Historie maniaków, 154.
} 
linked to a trend favouring parody, and he was also hailed as the precursor of a trend advocating the use of the grotesque in Polish literature. All the analysed elements in the presented world can be considered in terms of the grotesque, which is also visible in moments marked by situational humour. One of the more grotesque passages in the whole collection of short stories is the one about the will of Pichon, in which he gives his instructions to posterity on how to die: "It is best to die in spring when idle longing lives in the bones and the boredom of life pulsates tiringly in your ears, like the clatter of Good Friday rattles. Then self-willed dying comes as a good duty. Opposing it, like ordinary people tend to do, is not advisable in this case. It is better to surrender." 33 The Ars bene moriendi by Jaworski is rather trenchant and amusing in this trenchancy, and it stands as another example of valuing ugliness positively. Even in the face of death, he differentiates between "ordinary" people and contrasts them, by implication, with the "chosen ones," including the author of the will, Pichon, who was "endowed" with strabismus and marked by ugliness. The same character also used to engage in grotesque conversations in restaurants, discussing the statistics of suicides and sudden deaths, which met with the disapproval of his interlocutors: "Of course, he would scare his paler and paler audience, who - with a sweet grimace in the corners of their pupils - thanked the apostle of death for the fortifying retreat." ${ }^{\prime 34}$

The grotesque associated with the topos of death occupies a privileged position due to the topic of the collection. It is created by combining elements of humour with death, which is described with the use of ugliness. This is possible due to the similarity of both categories. The root of all the analogies leading to this can be found in deformation, distortion, incoherence, the essential determinants of ugliness, also creating phenomena defined as the grotesque. ${ }^{35}$ Ugliness, however, is a wider, more capacious, heterogeneous classification, from which the grotesque can be abstracted. It will be always possible to define the grotesque through the use of ugliness, while ugliness will not always constitute the grotesque: the cited examples are not always funny, or surprising, and some of the examples quoted point to the sadness, fear, or repulsion which it connotes.

\section{The significance of Jaworski's work today}

It comes as a surprise to see the state of literary research on the issue of ugliness and the grotesque in Historie maniaków, or - to be more precise - the blatant disproportion of the research clearly dominated by the narrative focusing on the aesthetics of the grotesque. ${ }^{36}$ Jaworski's collection of short

\footnotetext{
${ }^{33}$ Jaworski, Historie maniaków, 129.

${ }^{34}$ Jaworski, Historie maniaków, 121.

${ }^{35}$ Lech Sokół, Groteska w teatrze Stanisława Ignacego Witkiewicza (Wrocław: Zakład Narodowy im. Ossolińskich Wydawnictwo PAN, 1973), 27.

${ }^{36}$ Cf. Michał Głowiński, introduction to Roman Jaworski, Historie maniaków (Krakow: Wydawnictwo Literackie Krakow, 1978); Krzysztof Kłosiński, Wokót "Historii maniaków". Stylizacja. Brzydota. Groteska (Krakow: Wydawnictwo Literackie, 1992); Radosław OkuliczKozaryn, Gest Pięknoducha. Roman Jaworski i jego estetyka brzydoty (Warsaw: Wydawnictwo IBL
} 
stories was written at the beginning of the 20th century, when ugliness and grotesque were treated as synonymous: the terminology worked in favour of the grotesque at that time, the result of which ugliness lost its autonomy. Currently, these two aesthetic categories, despite being related, are no longer regarded as equivalent, yet Jaworski's work is still considered and interpreted mainly in terms of the category of the grotesque.

Reading his literary output in such a way does not fit into the writer's artistic vision and is not sufficient in light of contemporary literary research. The category of ugliness - valued positively by Jaworski and created in relation to the author's original aesthetics - is not only the background, but also a relevant component, with the help of which the writer accomplished the aesthetics of the grotesque widely discussed later. Jaworski exploited ugliness on every level of the construction of the text, ranging from the topic of the work, the way of characterising the physicality and psyche of the characters as well as the places where the story is set, to the innovative composition and idiosyncratic language of the text. Through the prism of that aesthetics, he looked primarily at the specificity of humanity and corporeality, often breaking a cultural taboo. Jaworski's stance corresponds to contemporary freak studies, i.e. studies concerning the subjectivity of bodies which are excluded due to the obscene, uncensored status of old age, illness and disability. ${ }^{37}$ Each of his characters was distinguished by a certain disability, which Jaworski did not marginalise: on the contrary, he turned it into a positive value in his axiology. In this way, he went beyond the canon of perceiving the non-normative carnality of his day.

The category of ugliness was used by Jaworski to parody the lyrically solemn style of Young Poland and its literary stereotypes: in this mocking way, he showed his distance to the stylistics prevalent at the time of his literary debut. Making ugliness the indicator of his writing, he developed an innovative and unique style, which had its followers. Jaworski was not only a precursor of the grotesque trend, but also of turpism, which in principle glorified ugliness and the everyday life embedded in it. The writer's literary output may be referred to as pre-turpism, or turpism of early modernism. Many of his postulates were later put into practice in literature. Jaworski's work could be described using the slogans of postmodernism, such as the deconstruction of aesthetic and ideological canons, the idea of the exhaustion of language, or even banalisation of literature and creating anti-literature. ${ }^{38}$ The writer was not only a literary phenomenon of his day, but he also significantly influenced the following generations of modern and postmodern artists.

PAN, 2003); Jerzy Maciejewski, Konstruktor dziwnych światów: groteskowe, ludyczne i karnawałowe aspekty prozy Romana Jaworskiego (Toruń: Uniwersytet Mikołaja Kopernika, 1990); Anna Kubale, "Próba analizy groteski Romana Jaworskiego." Wesele hrabiego Organza, Prace Humanistyczne, series I, no. 4 (1975); Katarzyna Zwierzchowska, “Twórczość Romana Jaworskiego początkiem nurtu parodystyczno-groteskowego w literaturze polskiej," Acta Universitatis Lodziensis. Folia Litteraria Polonica, no. 14/2 (2011): 131-142.

${ }^{37}$ Kazimiera Szczuka, "Groteska," in Encyklopedia gender..., 174.

${ }^{38}$ Włodzimierz Bolecki, "Modernizm w literaturze polskiej XX w." Teksty Drugie, no. 4 (2002): 11-34. 
Jaworski managed to highlight the instability of the canons of beauty and discredit them as a value which is no longer valid. In this way, he anticipated avant-garde movements whose supporters questioned the primacy of the category of beauty. In terms of aesthetics, Historie maniaków is close to camp - sublime aesthetics that assumed opposition to marginalisation and unambiguity, while giving primacy to values which tend to be rejected. Jaworski was guided by this imperative, as he repeatedly mentioned it in his texts. Camp uses mainly aesthetic devices. One hallmark of this sensitivity is the manifestation of unnaturalness: artificiality, exaggeration and hyperbolic expression, ${ }^{39}$ (i.e. features which comprise ugliness representing an aesthetic dominant in Jaworski's prose, and being, at the same time, a successful attempt to describe the poetics of the author). Currently, camp also assumes the perception of the surrounding reality as an aesthetic phenomenon, which was certainly close to Jaworski as a declared dandy. Hence, camp is a kind of ludic distortion of morality, because it treats not only the phenomena of an aesthetic nature but also those subject to ethical evaluation through the prism of aesthetic values. This element of ludicity resounds in Historie maniaków and is intended for entertainment and a struggle against boredom, even at the cost of transforming sacrum into profanum. Camp is manifested in Jaworski's writing by the triumph of the sublime style over the content, aesthetics over morality and mocking irony over seriousness, yet his stories lack features pointing to the camp concept of human identity and sexuality as camp in the broader sense also applies to the subversion of gender roles, or more generally, to a post-gender perception of the human being. ${ }^{40}$ At the end of the 20th century, the theatricalisation with its exaggerated gestures changed into enacting culturally established social roles, into stressing the most characteristic features and manners or, on the contrary, into glorifying the androgenic human being. Hence, Jaworski can be considered to be an author who writes in the camp aesthetics, or who represents a system of values similar to that articulated by camp.

Ugliness in Jaworski's work often expresses disgust. As Julia Kristeva pointed out, it is in literature that repulsion, together with disgust, accomplishes the fullness of its power. ${ }^{41}$ In order to stress the specific relationship between this part of culture and the primordial impulse of disgust, Kristeva draws on de Saussure's Theory of Signs: she calls literature the main signifier for disgust and aversion which causes it. Her words find confirmation in Jaworski's prose, which abounds in repulsion triggered by the use of ugliness. The full power of disgust in the case of Historie maniaków is manifested in the accuracy with which the writer evokes images, smells and sounds which cause disgust. What draws attention is the consistency with which Jaworski uses this type of imaging and the extent of this stylistic device:

${ }^{39}$ Maria Gołębiewska, “Kamp jako postawa estetyczna - o postmodernistycznych uwikłaniach," in Demontaż atrakcji. O estetyce audiowizualności (Gdańsk: słowo/obraz terytoria, 2003), 151-181.

${ }^{40}$ Przemysław Czapliński “Kamp - gry antropologiczne," in Kamp. Antologia przekładów, ed. Przemysław Czapliński, Anna Mizerka (Krakow: Universitas, 2012), 21.

${ }^{41}$ Kristeva, Potega obrzydzenia. Esej o wstręcie..., 193. 
the narration is conducted in such a way that repulsion affects every sense of the reader and does not remain indifferent with regard to the sphere of moral issues. The way in which the characters are shown, their appearance and behavior, highlighting their phobias, obsessions and perversions bring to mind the researcher's observations on the abject, or what is denied the right to be a subject. The characters in Jaworski's work are abjective: they evoke disgust, frighten and fascinate with their otherness, go beyond the symbolic order, do not fit into accepted social norms, and deviate from heteronormativity. Kristeva considered in the category of abject also those areas which were of particular interest to Jaworski: what they have in common is the reflection on corporeality visible in each short story comprising Historie maniaków as well as on perverse sexuality, which the author depicted in his short stories including "Trzecia godzina" and "Amor milczący." Therefore, it is justified to say that the subject of Jaworski's interest was the abject, to use today's terminology proposed by Kristeva.

In the case of Kristeva, disgust represents a line of demarcation, setting the boundaries of culture and protecting against a fall. Jaworski, in turn, aimed to provocatively introduce ugliness and repulsion into culture. He wanted the disgusting ugliness not to be marginalised any longer and he demanded that it should establish a new aesthetic canon. Using ugliness, he wanted to push the boundaries that Kristeva wrote about later, which makes his work fascinating and extremely up-to-date more than a century after its publication. As Magdalena Popiel notes: "It is a fact that the literature of Young Poland has been included in the current of intellectual ferment taking place nowadays owing to postmodernism." ${ }^{\prime 2}$

\section{REFERENCES}

Bolecki, Włodzimierz. "Modernizm w literaturze polskiej XX w.," Teksty Drugie, 4 (2002).

Czapliński, Piotr. “Kamp - gry antropologiczne." In Kamp. Antologia przekładów. Edited by Piotr Czapliński, Anna Mizerka. Krakow: Universitas, 2012.

Encyklopedia gender. Płeć w kulturze. Edited by Monika Rudaś-Grodzka, Katarzyna Nadana-Sokołowska, Agnieszka Mrozik, Kazimiera Szczuka, Katarzyna Czeczot, Barbara Smoleń, Anna Nasiłowska, Ewa Serafin, Agnieszka Wróbel. Warsaw: Czarna Owca, 2014.

Głowiński, Michał. "Sztuczne awantury." Introduction to Roman Jaworski. Historie maniaków. Krakow: Wydawnictwo Literackie Krakow, 1978.

Gołębiewska, Maria. "Kamp jako postawa estetyczna - o postmodernistycznych uwikłniach." In Demontaż atrakcji. O estetyce audiowizualności. Gdańsk: słowo/obraz terytoria, 2003.

${ }^{42}$ Magdalena Popiel, Oblicza wzniostości. Estetyka powieści młodopolskiej (Krakow: Universitas, 2003), 9. 
Jaworski, Roman. Historie maniaków. Warsaw: Biblioteka Analiz, 2004.

Kitrasiewicz, Piotr. Introduction to: Jaworski, Roman. Historie maniaków. Warsaw: Wydawnictwo Naukowe PWN, 2004.

Kłosiński, Krzysztof. Wokót "Historii maniaków”. Stylizacja, brzydota, groteska. Krakow: Wydawnictwo Literackie, 1992.

Kristeva, Julia. Potegga obrzydzenia. Esej o wstręcie. Translated by Maciej Falski. Krakow: Wydawnictwo Uniwersytetu Jagiellońskiego, 2007.

Menninghaus, Winfried. Wstręt. Teoria i historia. Translated by Grzegorz Sowiński. Krakow: Universitas, 2009.

Popiel, Magdalena. Oblicza wzniosłości. Estetyka powieści młodopolskiej. Krakow: Universitas, 2003.

Sokół, Lech. Groteska w teatrze Stanisława Ignacego Witkiewicza. Wrocław: Zakład Narodowy im. Ossolińskich, Wydawnictwo PAN, 1973.

Magdalena Sikorska - is a doctoral student in the Department of Literature and Tradition of Romanticism at the University of Lodz. Her research interests focus on the category of ugliness, its place in literature and contemporary humanistic discourse.

E-mail: mmm.sikorska@gmail.com 